\title{
Characterization of quality changes of whole super sweet corn (Zea mays saccharata Sturt.) during thermal sterilization for shelf-stable products
}

\author{
Yun Ju Lee ${ }^{1}$ Won Byong Yoon ${ }^{1,2}$ \\ 상온유통을 위한 가열살균 중의 통 초당옥수수의 품질변화 연구
}

이윤주 ${ }^{1} \cdot$ 윤원병 1,2

Received: 28 November 2018 / Accepted: 15 December 2018 / Published Online: 31 March 2019

(C) The Korean Society for Applied Biological Chemistry 2019

\begin{abstract}
This study investigated the quality changes in whole super sweet corn during thermal processing to extend its shelf-life. To minimize the reduction of unique texture of whole sweet corn after the sterilization, the alcohol sanitation applied and the cold point of a whole corn ear was determined using a computer simulation. The cold point was located between the corn kernel and the cob. The microorganisms on the surface of sweet corn were reduced by more than $1 \log \mathrm{CFU} / \mathrm{g}$ after alcohol sanitation, then the whole corn was treated to satisfy the degree of sterilization $\left(F_{121.1}=4\right)$. The quality of sterilized sweet corn was compared with the control that was treated with steaming. The quality changes of sterilized sweet corn during storage were monitored for 9 months at $25{ }^{\circ} \mathrm{C}$. The hardness was maintained within $30 \%$ of its initial value. The minimum of hardness was $464.50 \pm 103.35 \mathrm{~g}$ and maximum of hardness was $514.50 \pm 81.83 \mathrm{~g}$. The differences in the sugar content among the samples were found, but the sugar content of corn kernel remained within $30 \%$ of the control, ranging from $28.83 \pm 1.05$ to $34.36 \pm 0.42 \%$. The yellowness was higher than that of control by $5 \%$. The maximum
\end{abstract}

Won Byong Yoon $(\triangle)$

E-mail:wbyoon@kangwon.ac.kr

${ }^{1}$ Department of Food Science and Biotechnology, Kangwon National University, Republic of Korea

${ }^{2}$ Elderly-Friendly Food Research Center, Agriculture and Life Science and Research Institute, Kangwon National University, Republic of Korea

This is an Open Access article distributed under the terms of the Creative Commons Attribution Non-Commercial License (http://creativecommons. org/licenses/by-nc/3.0/) which permits unrestricted non-commercial use, distribution, and reproduction in any medium, provided the original work is properly cited. value of yellowness was $34.36 \pm 0.42$. The general bacteria and molds and yeasts in corn kernel stored at $25^{\circ} \mathrm{C}$ were not detected after 9 months of storage at $25{ }^{\circ} \mathrm{C}$. Therefore, in this study, we have demonstrated that the thermal sterilized method extends the shelf-life of whole sweet corn with minimizing its quality changes over 6 months in room temperature.

Keywords F-value Shelf-stable Sterilization $\cdot$ Sweet corn · Vacuum packaging

\section{서 론}

세계 3대 작물 중의 하나인 옥수수는 일반옥수수, 찰옥수수, 단 옥수수, 튀김옥수수 등 다양하게 분류되고 있으며 우리나라에서 는 대부분 찰옥수수를 재배하여 간식용, 가공용 등으로 이용하 고 있다[1]. 그 중에서도 단옥수수인 초당옥수수(Zea mays saccharata Sturt.)는 찰옥수수에 비해 당도가 높으며, 7가지 품 종의 풋초당옥수수 당도는 $10.8{ }^{\circ} \mathrm{brix}$ 에서 $19.8{ }^{\circ} \mathrm{brix}$ 의 범위를 가진다[2]. 초당옥수수의 높은 당도 및 식생활 습관의 서구화로 인하여 간식용, 가공용 등 국산 초당옥수수에 대한 국민적 관 심이 증가함에 따라 경북 고령, 전남 여수, 경기 평택 등지에서 초당옥수수의 재배가 증가하고 있다[3].

초당옥수수는 적기에 재배하도록 권장되고 있어 일시에 대량 출하되면 가격이 하락하고, 수확 후 품질저하가 빠르기 때문에 초당옥수수 재배에 어려움이 있다[4]. 또한, 국내에서 초당옥수 수는 여름철에 수확되고 있으며, 여름철 고온에서 수확되면 당 이 전분으로 변하는 속도가 빨라 감미가 빨리 떨어질 뿐만 아 니라 높은 당도로 인한 병해충의 피해로 품질이 저하되어 유통 기한이 짧다[5]. 초당옥수수의 원래 형태인 통옥수수를 유지한 
채로 소비자들에게 공급하기 위하여 초당옥수수는 수확 후 5 ${ }^{\circ} \mathrm{C}$ 이하의 저온 저장 혹은 냉동저장하여 유통한다. 이와 같이 초당옥수수는 저온 저장 시 장기간 품질유지를 할 수 없으므로 초당옥수수의 품질변화를 최소화하면서 유통기한을 증가시킬 기 술이 필요하다.

산업에서 식품의 품질을 유지하면서 유통기한을 연장시키기 위하여 가열공정을 이용해오고 있다[6]. 식품의 형상 및 크기에 따라 냉점의 위치가 변화하기 때문에 초당옥수수의 유통기한 연 장을 위한 살균 시 다양한 형상의 초당옥수수의 냉점의 위치를 정확하게 파악하는 것이 필요하다. 통조림 형태 초당옥수수는 기하학적으로 통조림 용기의 중심이 냉점이고, 다양한 식품 형 상에서 열전달에 의한 정확한 냉점을 파악하기 위하여 컴퓨터 시뮬레이션이 이용된다[7].

초당옥수수는 이와 같은 고유 특징으로 섭취 시 낟알이 아삭 아삭한 느낌을 준다[6]. 그러나 가열살균 이후 낟알의 아삭한 식감이 감소하며, 아스파라거스와 호박의 경우에도 가열처리 공 정 이후 조직감이 감소한다[8],[9]. 살균을 위한 가열시간을 최 소화 하기 위하여 비가열 전처리로서 초기 미생물 감균 효과가 있는 산, 알코올 침지가 이용되고 있다. 유통기한 연장을 위하 여 떡볶이 떡은 산침지 농도를 조절하여 조직감 변화를 최소화 하고, 초기 미생물을 감균한 후에 가열살균방법을 이용하였다 [10].

따라서 본 연구에서는 초당옥수수가 저장기간동안 품질변화 가 최소화하면서 상온에서 장기간 유통될 수 있는 최적 살균법 을 도출하는 것을 목표로 하고 있으며, 이를 위하여 초당옥수 수의 정확한 냉점을 파악한 후 저장기간에 따른 초당옥수수의 품질변화를 확인하였다.

\section{재료 및 방법}

\section{실험재료}

실험에 사용한 초당옥수수(주)식탁이 있는 삶, Seoul, Korea)는 구입 후 냉장보관하면서 통옥수수형태가 온전한 것으로서 초당 옥수수의 총 길이가 $15 \mathrm{~cm}$ 이상이고 무게가 $174 \mathrm{~g}$ 이상인 것을 10 일 이내에 사용하였다. 이후 반복 실험을 위하여 지속적으로 동일한 제품을 구매 후 동일한 방법으로 보관하면서 실험에 사 용하였다. 초당옥수수의 진공포장용 포장재는 Polyethylene (PET), Nylon (Ny), Coextruded cat polypropylene (CPR)로 구성된 포장재((주)하우패키지, Yangju, Korea)를 사용하였다.

\section{알코올 처리}

가로, 세로가 $10 \mathrm{~cm} \times 10 \mathrm{~cm}$ 인 멸균거즈((주)우주위재상사, Goryeong, Korea)에 95\% 발효주정((주)대한주정 라이프, Seoul, Korea)을 $10 \mathrm{~mL}$ 도포한 것으로 통초당옥수수의 표면을 닦았다.

\section{열전달 시뮬레이션}

통초당옥수수의 정확한 냉점을 파악하기 위하여 $\mathrm{COMSOL}$ version 5.2a Multiphysics 소프트웨어(COMSOL, Inc., Stockholm, Sweden)를 이용하여 열전달 시뮬레이션을 진행하였다. 통초당 옥수수의 형상은 버니어 캘리퍼스(BLUEBIRD, Hongkong,
China)를 이용하여 실제 통초당옥수수의 크기와 동일하게 하였 으며, 시뮬레이션에 필요한 초당옥수수의 속대와 낟알의 비열과 열전도도는 열분석기(KD2 Pro, Decagon Devices, Pullman, WA, USA)를 사용하여 $20^{\circ} \mathrm{C}$ 에서 $100{ }^{\circ} \mathrm{C}$ 까지 온도변화에 따른 측정 값을 사용하였다. 레토르트 가열에 의하여 초당옥수수 내 부 전도에 의한 열전달 시뮬레이션에 사용된 비정상 상태의 Fourier의 지배 방정식은 다음과 같이 구하였다:

$$
\frac{\partial T}{\partial t}=\frac{k}{\rho C_{p}}\left(\frac{\partial^{2} T}{\partial z^{2}}+\frac{\partial^{2} T}{\partial r^{2}}\right)=\alpha\left(\frac{\partial^{2} T}{\partial z^{2}}+\frac{\partial^{2} T}{\partial r^{2}}\right)
$$

$\mathrm{T}$ 는 초당옥수수의 온도 $\left({ }^{\circ} \mathrm{C}\right)$; t는 시간 $(\mathrm{min}) ; \mathrm{r}$ 은 반지름 방향; $\mathrm{z}$ 는 수직 방향; $\alpha$ 는 열 확산 계수 $\left(\mathrm{m}^{2} / \mathrm{s}\right)$ 이며, 초당옥수수 낟알의 밀도 $(\rho)$ 는 $212.11 \mathrm{~kg} / \mathrm{m}^{3}$, 초당옥수수 속대의 밀도는 $1,119 \mathrm{~kg} / \mathrm{m}^{3}$ 값을 사용하였다. 초기 조건은 다음과 같이 설정하였다:

$$
T(z, r, 0)=T_{0}
$$

그리고 초당옥수수의 외부 경계 조건은 다음과 같이 설정하였다:

$$
\begin{aligned}
& -k\left(\frac{\partial T}{\partial r}\right)=h\left(T_{c}-T_{s}\right) \\
& -k\left(\frac{\partial T}{\partial z}\right)=h\left(T_{c}-T_{s}\right)
\end{aligned}
$$

$T_{c}$ 는 초당옥수수의 표면 온도 $\left({ }^{\circ} \mathrm{C}\right), T_{s}$ 는 레토르트의 수증기 온도, $h$ 는 열 전달 계수 $\left(\mathrm{W} / \mathrm{m}^{2}, \mathrm{~K}\right), k$ 는 열전도도이다. 레토르트 수증 기의 속도는 측정하는 것이 어렵기 때문에 레토르트 내부의 강 제 대류에 의한 열 전달 계수는 $200-2,000 \mathrm{~W} / \mathrm{m}^{2}, \mathrm{~K}$ 의 범위를 가지며[7], 본 시뮬레이션에서는 열 전달 계수의 값을 $200 \mathrm{~W} /$ $\mathrm{m}^{2}, \mathrm{~K}$ 로 하였다.

\section{가열처리}

대조군인 초당옥수수는 증숙기(W-457, 리빙월드, Anseong, Korea) 에서 30 분 동안 가열한 것을 사용하였다. 실험군인 초 당옥수수는 비가열처리한 초당옥수수를 진공포장한 후 레토르 트(SR-240, TOMY, Osaka, Japan) 가열처리를 하였다. 레토르 트 가열처리 시 초당옥수수의 온도 측정은 무선온도센서 (Tracksense ${ }^{\circledR}$ pro, Ellab, Trollesmindealle, Hillerød, Denmark)를 이용하여 측정하였으며, 살균도는 다음과 같이 구하였다[11].

$$
F_{r e f}=\int_{0}^{t} 10^{\frac{T(t)-T_{r e f}}{z}} d t
$$

$t$ 는 살균 시간 $(\mathrm{min}), T(t)$ 는 살균 시간 $\mathrm{t}$ 일 때 무선 온도 센서로 측정한 온도 $\left({ }^{\circ} \mathrm{C}\right), T_{r e f}$ 는 $121.1{ }^{\circ} \mathrm{C}$ 로 하였으며, $z$-value는 $10^{\circ} \mathrm{C}$ 로 하였다.

\section{당도측정}

초당옥수수 낟알 $10 \mathrm{~g}$ 과 증류수 $20 \mathrm{~mL}$ 를 균질화 한 후 $0.2 \mu \mathrm{m}$ 시린지 필터(Syringe filter, Minisart RC15, Sartorius, Goettingen, Germany)를 사용하여 여과한 액체 $1 \mathrm{~mL}$ 를 당도계(Poket PAL$\alpha$, ATAGO, Tokyo, Japan) 로 측정하였다. 


\section{색도측정}

초당옥수수의 표면의 색도 변화를 확인하기 위하여 색도계(CR300 , Minolta, Osaka, Japan)를 사용하여 황색도(b)를 3반복 측 정하여 그 평균 값으로 나타내었다. 이때 사용된 Calibration plate는 L값이 94.50, a값이 .3126, b값이 .3191이었다.

\section{조직감측정}

초당옥수수의 가열처리에 따른 조직감 변화와 저장기간 동안의 조직감 변화를 확인하기 위하여 초당옥수수 낟알의 조직감을 측 정하였다. 측정 시 낟알 1 개를 채취하여 Texture analyzer (CT3, Brookfield, Stoughton, MA, USA)를 이용하여 compression test 측정을 하였다. Texture analyzer에 사용한 프로브는 실린더 형 프로브 TA41 (직경 $6 \mathrm{~mm}$ )를 이용하여 8회 반복 측정을 하 였다. 측정 시 기기의 조건은 deformation $20 \%$, test speed는 $0.5 \mathrm{~mm} / \mathrm{s}$, trigger load는 $7 \mathrm{~g}$ 으로 설정하였다.

\section{미생물검사}

비가열 전처리 후와 비가열 전처리 후 가열처리를 한 초당옥수 수의 미생물 수를 확인하기 위하여 미생물 검사를 진행하였다. 미생물 실험은 9 개월 동안 $25^{\circ} \mathrm{C}$ 인큐베이터에 저장한 초당옥 수수 샘플을 1 달 간격으로 초당옥수수 낟알의 일반세균 및 진 균류 검사를 하였다. 일반세균과 진균류 검사를 위하여 초당옥 수수 낟알 $10 \mathrm{~g}$ 과 $0.1 \%$ 펩톤수 $90 \mathrm{~mL}$ 를 균질화 한 후 희석액 $1 \mathrm{~mL}$ 을 취하여 일반세균 확인을 위하여 plate count agar plate (PCA; BD-Difco, Sparks, MD, USA)에 도말 하였으며, 진균류 확인을 위하여 potato dextrose agar plate (PDA; BD-Difco, Sparks, $\mathrm{MD}, \mathrm{USA})$ 에 도말 하였다. 도말 된 일반세균과 진균류 의 plate는 $35{ }^{\circ} \mathrm{C}$ 의 인큐베이터에서 48 시간 배양한 후 생성된 colony의 수를 계수하였다.

\section{통계분석}

본 연구의 실험은 최소 3 회 이상 반복 측정하였으며, SPSS 통 계프로그램(version 23.0, SPSS Institute Inc., Chicago, IL, USA)을 사용하여 실험결과의 차이를 분산분석(ANOVA)을 통 하여 $p<0.05$ 수준에서 Duncan's multiple range test로 시료 간 유의성을 검정 하였다.

\section{결과 및 고찰}

\section{비가열 전처리}

통초당옥수수의 상온에서 유통기한 확보를 위하여 살균 시 초 당옥수수의 고유한 특징인 아삭아삭한 식감의 변화를 최소화 하 기 위하여 가열살균 이전에 알코올 전처리를 진행하였다. 비가 열 전처리 결과(Table 1)에서 아무 처리를 하지 않은 생초당옥 수수(Raw)의 일반세균의 균수는 $7.54 \pm 0.04 \log \mathrm{CFU} / \mathrm{g}$, 진균류 의 균수는 $7.69 \pm 0.00 \log \mathrm{CFU} / \mathrm{g}$ 이었다. 알코올 전처리를 통한 초기 균수의 감균을 확인 결과, 일반세균의 균수는 $7.69 \pm 0.04$ $\log \mathrm{CFU} / \mathrm{g}$, 진균류의 균수는 $7.89 \pm 0.36 \log \mathrm{CFU} / \mathrm{g}$ 으로 알코올 전처리를 한 초당옥수수의 일반세균은 $1.27 \log \mathrm{CFU} / \mathrm{g}$, 진균류 는 $2.4 \log \mathrm{CFU} / \mathrm{g}$ 감소하였다. 이를 통하여 알코올 전처리는 초기 미생물 수를 $1 \log \mathrm{CFU} / \mathrm{g}$ 이상 감소시켰기 때문에 가열
Table 1 Populations $\left(\log _{10} \mathrm{CFU} / \mathrm{g}\right)$ of total aerobic bacteria and molds and yeasts according to Alcohol treatment of sweet corn

\begin{tabular}{ccc}
\hline \hline & Raw & Alcohol treatment \\
\hline $\begin{array}{c}\text { Total aerobic bacteria } \\
(\log \text { CFU/g) } \\
\begin{array}{c}\text { Molds and yeasts } \\
(\log \text { CFU/g) }\end{array}\end{array}$ & $7.54 \pm 0.04$ & $6.27 \pm 0.04$ \\
\hline
\end{tabular}

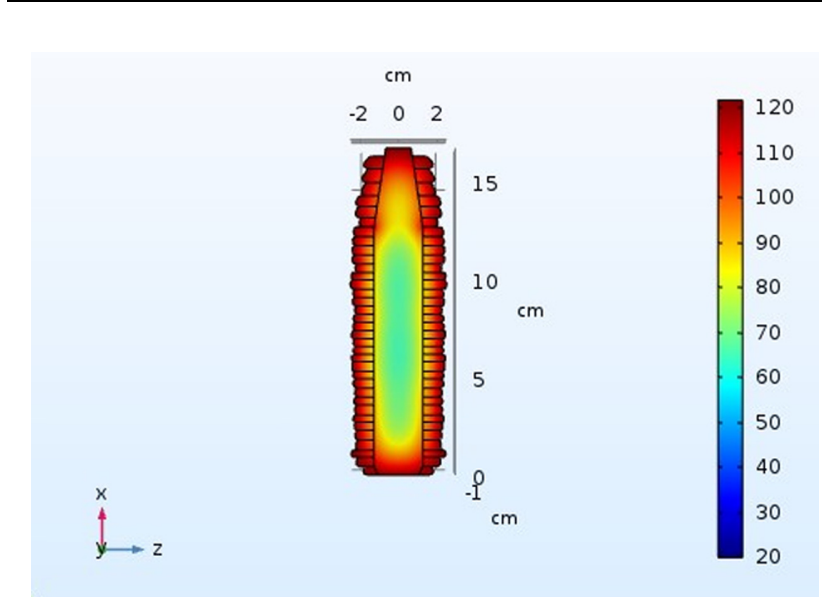

Fig. 1 The cold point of whole corn ear that founded at a point between the corn kernel and the bob

살균도를 낮출 수 있는 것을 확인하였다. 이와 유사하게 생면 의 경우 품질변화를 막고 저장성을 증가시키기 위하여 생면을 주정에 침지 하거나 주정을 첨가하는 연구가 이루어진 바 있다 [12].

\section{초당옥수수의 냉점 확인}

통초당옥수수의 경우 가열살균 시 온도가 가장 느리게 상승하 는 지점인 냉점의 위치는 초당옥수수의 중심이 아니기 때문에 냉점의 위치를 파악하는 것이 중요하다. 통초당옥수수의 정확한 냉점의 위치를 파악하기 위하여 레토르트 가열처리조건에서 열 전달 시뮬레이션을 진행한 결과 냉점의 위치는 Fig. 1에 나타 내었다. 통초당옥수수의 냉점을 속대 중심으로 정하면 초당옥수 수의 낟알이 과살균이 된다. 초당옥수수의 품질변화를 최소화하 는 최적 가열살균 방법을 도출하기 위하여 초당옥수수의 냉점 의 위치를 속대와 낟알 사이로 하였으며, 온도가 가장 느리게 상승하는 위치는 초당옥수수의 바닥 부분으로부터 $6.62 \mathrm{~cm}$ 떨 어진 부분인 것을 확인하였다. 이와 같이 살균 시 정확한 냉점 의 위치를 파악하기 위하여 열전달 시뮬레이션이 이용되며, 통 조림 식품과 같이 캔 내부에 액체 식품이 포장되어 있는 경우 $90{ }^{\circ} \mathrm{C}$ 의 온도에서 살균 시 냉점의 위치를 파악 하기 위하여 열 전달 시뮬레이션이 진행된 바 있다[13].

\section{초당옥수수의 가열살균}

통초당옥수수의 살균도를 도출하기 위하여 열전달 시뮬레이션 을 통해 도출한 냉점의 위치에서 레토르트 가열에 의하여 시간 에 따른 온도변화를 Fig. 2에 나타내었다. 일반적으로 미생물적 으로 안전하고 식품의 고유한 조직감을 유지할 수 있는 살균도 $\left(F_{0}\right.$-value)로서 5 분이 사용 된다[14]. 본 연구에서는 초당옥수 


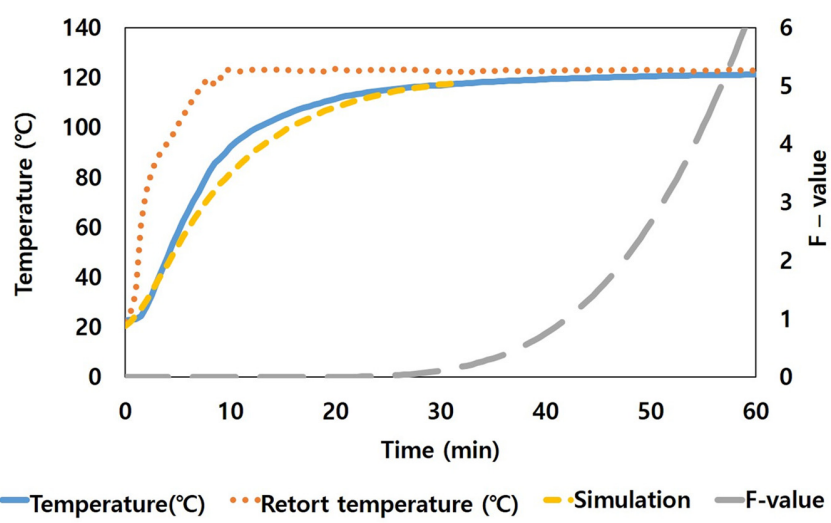

Fig. 2 Time-temperature profile of cold point of whole sweet corn during sterilization

수의 고유 조직감의 변화를 최소화 하기 위하여 비가열 전처리 로서 초기 미생물 수의 $1 \log \mathrm{CFU} / \mathrm{g}$ 을 감소시켰기 때문에 $F_{0^{-}}$ value $=4$ 분을 도출하고자 식 (6)를 통하여 살균시간을 도출하였 다. 초당옥수수의 냉점의 온도에서 $F_{0}$-value $=4$ 분을 만족시키는 시간은 54 분이었다. 이와 유사하게 해삼 병조림을 $F_{0}$-value=6분 을 만족시키는 레토르트 가열살균을 적용하여 저장 4주간의 품 질변화(길이, 부피, 무게)를 확인하는 연구가 진행된 바 있다 [15]. 또한, 레토르트 조미 홍합의 제품을 $F_{0}$-value=7, 10, 13분 을 만족시키는 살균 후 저장기간 동안 품질변화(휘발성 염기 질 소, 색, $\mathrm{TBA}$ 값, 아미노 질소 함량, 조직감 등)를 확인하여 최 적 살균도를 도출하는 연구가 진행된 바 있다[16].

비가열 및 가열살균 후 저장기간에 따른 초당옥수수의 품질변화 알코올 전처리 후 레토르트 가열살균한 초당옥수수의 저장기간 별 당도의 변화는 Fig. 3에 나타내었다. 대조군인 초당옥수수의 당도는 $14.38 \pm 4.32 \%$ 이었으며, 실험군인 초당옥수수의 당도 값 은 저장기간동안 최소 $10.20 \pm 0.23 \%$, 최대 $15.45 \pm 0.30 \%$ 을 나타 내었다. 저장기간동안 실험군인 초당옥수수의 당도는 유의미한 차이가 있었으며, 이는 비가열 및 가열살균 하기 이전의 풋초 당옥수수일 때부터 초당옥수수마다 당도 값(Table 2)이 유의미 한 차이가 있었기 때문이다. 풋초당옥수수를 무작위로 선택한 것을 Sample 1, Sample 2, Sample 3으로 하여 당도 측정 시 풋초당옥수수 샘플간 유의미한 당도 차이가 있는 것을 확인할 수 있었으며, 이를 통하여 저장기간별 당도의 변화는 가열살균 에 의한 변화가 아니라 풋초당옥수수 샘플간의 당도 차이에 의 한 것이다. 단옥수수는 수확한 후 저장온도에 따라 맛이 달라 지며 전당함량은 $10^{\circ} \mathrm{C}$ 이하에서 보관 시 감소량은 적었으나 $15{ }^{\circ} \mathrm{C}$ 이상에서는 저장기간이 길어질수록 급격히 감소하였으며 fructose와 glucose 보다는 수확 시 함량이 많았던 sucrose가 주 로 감소하였다는 연구결과가 보고된 바 있다[17]. 이를 통하여 수확된 초당옥수수가 저온저장고에 저장 후 수요량에 따라 여 름철 상온에서 배송되기 때문에 다소 당도의 차이가 있는 것으 로 추정된다. 전반적으로 저장기간별 실험군 초당옥수수의 당도 는 대조군의 당도 대비하여 $30 \%$ 이내를 유지하였다.

비가열 및 가열살균 후 저장기간에 따른 초당옥수수 표면의 황색도 변화를 Fig. 4에 나타내었다. 대조군의 황색도는 $28.43 \pm$ 0.70 이었으며, 실험군의 황색도는 저장기간동안 최소 $29.41 \pm 1.31$,

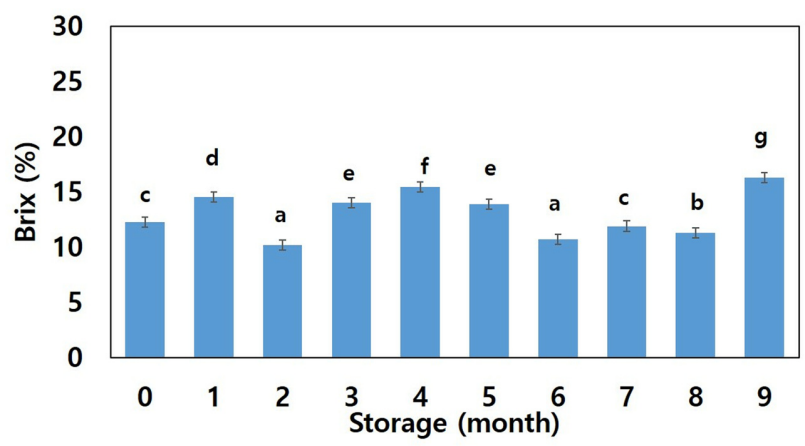

Fig. 3 The sugar content (\%) of optimum-sterilized sweet corn storage period

Table 2 Sugar content (\%) of raw sweet corn

\begin{tabular}{cccc}
\hline \hline & Sample 1 & Sample 2 & Sample 3 \\
\hline Average \pm SD & $13.10 \pm 1.14^{\mathrm{a}}$ & $12.30 \pm 0.30^{\mathrm{b}}$ & $11.00 \pm 0.62^{\mathrm{b}}$ \\
\hline
\end{tabular}

${ }^{\mathrm{a}-\mathrm{b}}$ Value with different superscripts within a column are significantly different at $p<0.05$

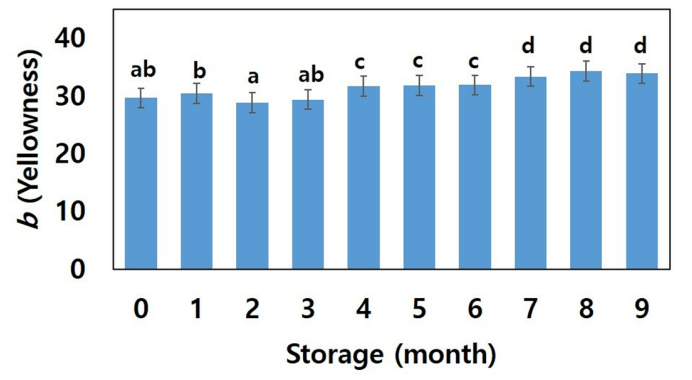

Fig. 4 The yellowness of optimum-sterilized sweet corn storage period

최대 $34.36 \pm 0.42$ 의 범위를 나타내었다. 이를 통하여 실험군의 황색도는 대조군의 황색도 대비 $5 \%$ 이상 증가함을 확인하였다. 증숙과 같이 $100{ }^{\circ} \mathrm{C}$ 에서 가열하는 것보다 $121.1{ }^{\circ} \mathrm{C}$ 의 고온에서 가열 시 황색도가 증가하였으며, 이와 유사하게 옥수수를 $115^{\circ} \mathrm{C}$ 에서 40 분간 처리한 옥수수의 황색도 보다 $121^{\circ} \mathrm{C}$ 에서 10 분간 처리한 옥수수의 황색도가 증가한 연구가 진행된 바 있다[18].

저장기간 동안 비가열 및 가열처리한 초당옥수수의 경도 변 화는 Fig. 5에 나타내었다. 초당옥수수 대조군의 경도는 603.17 $\pm 41.05 \mathrm{~g}$ 이었으며, 실험군의 경도는 최소 $464.50 \pm 103.35 \mathrm{~g}$, 최대 $565.00 \pm 75.20 \mathrm{~g}$ 이었다. 이를 통하여 실험군의 조직감은 대조군 의 조직감 대비 $30 \%$ 이내를 유지함을 확인하였다. 저장기간동 안에 초당옥수수의 조직감이 유의미한 차이가 존재하는 것은 같 은 품종의 초당옥수수 이삭이라 할지라도 이상의 여뭄 등 균일 성 정도에 의한 차이이다[18].

비가열 및 가열살균한 초당옥수수를 $25^{\circ} \mathrm{C}$ 인큐베터에서 9 개 월간 저장하면서 저장기간 동안 1 개월 간격으로 초당옥수수의 일반세균과 진균류 검사한 결과 모두 균이 검출되지 않은 것을 확인하였다(Table 3). 저장기간 9개월 동안 비가열 및 가열살균 한 초당옥수수에서 일반세균 및 진균류가 검출되지 않아 미생 물학적 측면에서는 상온에서 최소 6 개월 이상 안전한 것임을 확인하였다. 또한 비가열 및 가열살균 후 6개월 동안 미생물학 


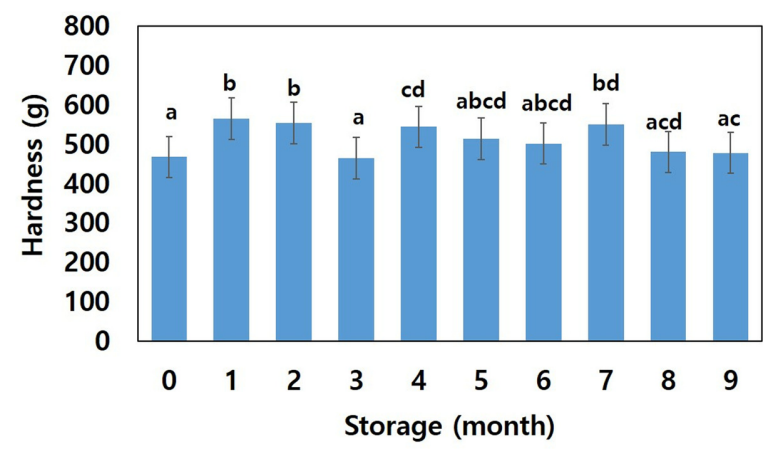

Fig. 5 The hardness (g) of optimum-sterilized sweet corn during storage period

적 안전성이 확보됨과 동시에 초당옥수수의 당도, 조직감이 대 조군과 비교 시 $30 \%$ 이내 유지하였으며, 황색도의 경우 대조 군에 비해 $5 \%$ 이상 증가한 것을 통하여 이와 같은 방법이 통 초당옥수수의 최적 살균법임을 확인하였다. 본 연구에서 통초당 옥수수에 적용한 최적 살균법은 6개월 이상 상온유통이 가능하 면서 유통기한 동안 초당옥수수의 품질변화를 최소화하는 기술 임을 확인하였다. 이러한 기술은 레토르트 맛밤 제품, 야채 제 품 등에 적용하여 가열에 의한 식품의 조직감 감소를 최소화하 고 식품 본연의 식감을 살리면서 유통기한을 확보할 수 있는 기술로 응용될 수 있을 것이라 사료된다. 이와 유사하게 레토 르트 살균한 육류 볶음밥 제품을 저장기간동안 이화학적, 관능 적 품질변화 측정 및 미생물학적 품질변화 측정을 통하여 저장 기간 동안 이화학적 변화가 유의미한 차이가 없었으며, 생균수 의 경우 음성 결과가 나온 것을 통하여 유통기한 확보를 한 연 구가 진행된 바 있다[19].

\section{초 록}

본 연구에서는 상온 저장이 가능하며 별도의 처리 없이 바로 섭취할 수 있는 통초당옥수수를 위한 최적 살균법을 도출하고 저장기간동안 최적 살균된 초당옥수수의 품질인자를 분석하였 다. 살균 시 유통기한 확보 및 초당옥수수의 고유한 특징인 아 삭한 식감이 가열처리에 의하여 감소되는 것을 최소화 하기 위 해 비가열 전처리 공정으로서 알코올 세척을 도입하였으며, 냉 점은 초당옥수수의 속대와 중심 사이로 하였다. 초당옥수수의 표면은 알코올 세척을 통하여 $1 \log \mathrm{CFU} / \mathrm{g}$ 이상을 감소시킨 후 $F_{121.1}=4$ 분을를 만족하도록 가열하여 $25^{\circ} \mathrm{C}$ 인큐베이터에서 9개월간 저장하면서 대조군으로서 일반적인 증숙의 방법으로 가
열한 초당옥수수의 품질과 비교하였다. 알코올 처리 및 가열 살 균한 초당 옥수수의 조직감은 대조군의 조직감 대비 $30 \%$ 이내 를 유지하여 최소 $464.50 \pm 103.35 \mathrm{~g}$ 에서 최대 $514.50 \pm 81.83 \mathrm{~g}$ 값 을 나타내었으며, 당도는 샘플 간의 차이가 다소 있었으나 최 소 $28.83 \pm 1.05 \%$ 에서 최대 $34.36 \pm 0.42 \%$ 값으로 대조군에 대비하 여 $30 \%$ 이내 당도를 유지하였다. 초당 옥수수 겉표면 황색도 는 대조군 대비 $5 \%$ 이상 향상되어 최대 $34.36 \pm 0.42$ 값을 나타 내었으며, 미생물 검사에서는 일반세균과 진균류가 저장 9개월 동안 검출되지 않았다. 이러한 연구결과는 가열살균한 초당옥수 수의 품질변화가 최소화되면서 6 개월 이상의 상온유통이 가능 한 최적 살균 방법을 도출하였으며, 이에 따라 가열에 의하여 식품 본연의 조직감 감소를 최소화하면서 상온유통이 가능한 살 균제품에 이용될 수 있다.

Keywords 살균 - 살균도 - 상온저장 - 진공포장 - 초당옥수수

감사의 글 2018년도 강원대학교 대학회계 학술연구조성비로 연구하였음 (관리번호-520170193). 이 논문은 2018년도 정부(교육부)의 재원으로 한국연 구재단의 지원을 받아 수행된 기초연구사업임(No. NRF-2018R1D1A3B0 6042501).

\section{References}

1. Hallauer AR (2001) Specialty Corns. CRC Press 155-197

2. Zhu S, Mount JR, Collins JL (1992) Sugar and soluble solids changes in refrigerated sweet corn (Zea mays L). J Food Sci 57: 454-457

3. Lee JS, Jung TW, Son BY, Shin SH, Kin ST, Bae HH, Baek SB, Ku HK, Hwang JJ, Kin SL, Kim SK, Kwon YU (2014) A yellow sweet corn hybrid with high sugar content and lodging tolerance, 'Godangok'. Korean J Breeed Sci 46: 476-480

4. Lee SS, Kim TJ, Park JS (1987) Sugars, soluble solids and flavor as influenced by maturity of sweet corn. Korean J of Crop Sci 32(1): 86-91

5. Yang SK, Hong SB, Lee SS (2007) Planting time for the economic yield of a super sweet corn hybrid in the southern part of Korea. Korean J Crop Sci 52: 325-333

6. Shafiekhani S, Zamindar N, Hojatoleslami M, Toghraie D (2016) Numerical simulation of transient temperature profiles for canned apple puree in semi-rigid aluminum based packaging during pasteurization. J Food Sci Technol 53: 2770-2778

7. Hong YK, Uhm JT, Yoon WB (2014) Using numerical analysis to develop and evaluate the method of high temperature Sous-vide to soften carrot texture in different-sized packages. J Food Sci 47: 305-310

8. Lau MH, Tang J, Swanson BG (2000) Kinetics of textural and color changes in green asparagus during thermal treatments. J Food Eng 45: 231-236

9. Goncalyes EM, Pinheiro J, Abreu M, Brandão TRS, Silva CL (2007) Modelling the kinetics of peroxidase inactivation, colour and texture changes of pumkin (Cucurbita maxima L.) during blanching. J Food Eng 81: 693-701

Table 3 Populations $\left(\log _{10} \mathrm{CFU} / \mathrm{g}\right)$ of total aerobic bacteria and molds and yeasts during 9 months at $25^{\circ} \mathrm{C}$

\begin{tabular}{|c|c|c|c|c|c|}
\hline & 0 month & 1 month & 2 month & 3 month & 4 month \\
\hline Total aerobic bacteria $(\log \mathrm{CFU} / \mathrm{g})$ & N.D. & N.D. & N.D. & N.D. & N.D. \\
\hline \multirow[t]{2}{*}{ Molds and yeasts (log CFU/g) } & N.D. & N.D. & N.D. & N.D. & N.D. \\
\hline & 5 month & 6 month & 7 month & 8 month & 9 month \\
\hline Total aerobic bacteria $(\log \mathrm{CFU} / \mathrm{g})$ & N.D. & N.D. & N.D. & N.D. & N.D. \\
\hline Molds and yeasts $(\log \mathrm{CFU} / \mathrm{g})$ & N.D. & N.D. & N.D. & N.D. & N.D. \\
\hline
\end{tabular}


10. Jung HB, Yu CR, Park HW, Yoon WB (2018) Effect of soaking and thermal sterilization on the shape and quality characteristics of Tteokbokki rice cake. Korean J Food Nutr 31: 737-750

11. Park HW, Yoon WB (2018) Computational fluid dynamics (CFD) modelling and application for sterilization of food: A Review. Processes 6: 62

12. Lee JW, Lee HH, Rhim JW (2000) Shelf life extension of white rice cake and wet noodle by the treatment with chitosan. Korean J Food Sci Technol 32: 828-833

13. Lee MG, Yoon WB (2014) Developing an effective method to determine the deviation of $F$ value upon the location of a still can during convection heating using CFD and subzones. J Food Process Eng 37: 493-505

14. Ohlsson T (1981) Optimal sterilization temperature for flat containers. J Food Sci 45: 848-852

15. Kim YS, Yoon WB (2017) Effect of the rehydration cycles on the quality changed of retorted sea cucumber (StichopusJapinicus) during storage. Food Eng Prog 21: 29-35

16. Noh YN, Yoon HD, Kong CS, Nam DB, Park TH, Kim JG (2011) Preparation of retort pouched seasoned sea mussel and its quality stability during storage. J Kor Soc Fish Mar Edu 23: 709-722

17. Kim SL, Park SU, Cha SW, Seo JH, Jung TW (1987) Changes of major quality characters during grain filing in waxy corn and super sweet corn. Korean J Crop Sci 32: 137-143

18. Heo NK, Kim KD, Choi BG, Kim KH, Min HK, Kown HJ (2005) Improvement of storaging ability of waxy corn by retort pouch technique. Korean J Crop Sci 50: 147-151

19. Jeong SH, Ha JH, Jeong YG, JO BC, Kim DH, Ha SD (2011) Estimation of shelf-life of commercially sterilized fried rice containing meat. J Food Hyg Saf 26: 209-213 